O. Y. Khomko, B. V. Petryuk, L. P. Khomko, R. I. Sydorchuk, T. A. Petryuk, I. V. Zazulia

Bukovinian State Medical University

\section{APPLICATION OF GALVANOENTEROSORPTION IN MULTIMODAL TREATMENT OF PATIENTS WITH THERMAL BURNS}

\begin{abstract}
Aim - to investigate the influence of enterosorption and its combination with intra-tissue electrophoresis (ITE) of antibacterial preparations on the proteolytic and fibrinolytic activity of blood plasma in patients with common thermal burns.

Material and methods. Enterosorbtion detoxification by enterosgel was used in the multimodal treatment of 28 patients with thermal burns of II-IV stages. The drug was prescribed from 2-3 days after burn for 7-14 days, depending on the severity of the injury and manifestations of the intoxication syndrome. In 24 patients the treatment was complemented by galvanization of burn wounds with the preliminary introduction of antibacterial drugs. ITE began with 3-4 days after burn, taking into account the sensitivity of the microflora to antibiotics. The comparison group was made up of 30 patients with similar areas and depths of thermal burns receiving traditional treatment.

Results and discussion. It was discovered that the inclusion of enterosorption in multimodal therapy of burns diminished the level of unlimited proteolysis, favoured the increase of the level of blood plasma fibrinolytic activity. Its combination with ITE of antibacterial agents (galvanoenterosorption) ensured a higher therapeutic effect. Common deep thermal burns are accompanied by a significant increase in proteolytic and fibrinolytic activity (FA) of blood. Inclusion of enterosorbtion in the integrated therapy of burns provides reduction of proteolytic activity and maintenance of a high level of FA of plasma, which reduces the risk of thromboembolic complications.

Conclusion. Combined use of enterosorption and ITE of antibacterial agents (galvanoentersorption) with thermal burns provides a higher therapeutic effect.

Key words: thermal burns, enterosorption, intratissue electrophoresis, galvanoenterosorption.
\end{abstract}

\section{Introduction}

Thermal burns remain an important problem in the clinic of surgical diseases. Particularly problematic are extensive and profound lesions that are accompanied by the development of burn disease, the presence of severe intoxication syndrome, determined by various factors, including the intestinal factor [1, 2, 3, 4]. Along with other methods of detoxification, this presupposes the use of enterosorption $[5,6]$. The acute period of burn disease is accompanied by pronounced proteolysis of proteins, the level of which is directly proportional to the total area of damage [7, 8].

In case of thermal damage of skin, the coagulation potential of blood is activated, accompanied by the consumption of fibrinogen, heparin, antithrombin-III with the formation of fibrin [9]. Common deep burns are also accompanied by consumption of antiplasmins, which leads to activation of fibrinolytic processes, improvement of rheological properties of blood, but the products of fibrinogen-fibrin degradation are limited by the intravascular coagu- lation of the blood while providing the lysis of not yet folded fibrinogen and its complexes [10].

\section{The aim of the study}

To investigate the influence of enterosorption and its combination with ITE of antibacterial preparations on the proteolytic and fibrinolytic activity of blood plasma in patients with common thermal burns.

\section{Material and methods}

Enterosorbtion detoxification by enterosgel was used in the complex treatment of 28 patients with common thermal burns of II-IV stages. (ITU (70,6 $\pm 6,8$ units) $-\mathrm{D}$ gr. The drug was prescribed from 2-3 days after burn for 7-14 days, depending on the severity of the injury and manifestations of the intoxication syndrome. In the 24 patients (ITU $(73,5 \pm 7,2)$ units) this treatment was complemented by galvanization of burn wounds with the preliminary introduction of antibacterial drugs (D1 gr). ITE began with 3-4 days after burn, tak- 
ing into account the sensitivity of the microflora to antibiotics. Sessions (7-14) were conducted at a time when the concentration of drugs in blood reached the maximum level: during intravenous infusions, 30-40 minutes after intramuscular injections, 1 hour after oral administration. ITE was carried out with a constant current of $0,03-0,05 \mathrm{~mA} / \mathrm{cm} 2$ during 45-60 minutes using a galvanic apparatus "Potok-1". The comparison group (K gr.) was made up of 30 patients with similar areas and depths of thermal burns receiving traditional treatment.

The proteolytic activity of plasma was determined by the lysis of azoalbumin, azocollagen, azocasein. Fibrinolytic activity was studied by the azofibrin lysis with the definition of total, non-fermentative and enzymatic fibrinolytic activity (TFA, NFA, EFA). The research was conducted on the days 1-3, 6-7, 13-14 and 19-21 from the moment of burn.

\section{Results of the research and their discussion}

In the period of burn shock, the intensity of proteolytic degradation of low molecular weight plasma proteins (azo-albumin) exceeded the rate of healthy persons by 2.4 times.

At days 6-7 its level decreased in the main groups - respectively by $28.7 \%$ and $38.6 \%$ (Table 1 ).

After 13-14 days in K gr. it slightly increased and decreased moderately in the main groups, where it was $36.5 \%$ and $47.3 \%$, respectively, lower than in the first observation period. At the same time, the difference with $\mathrm{K}$ gr. was $35.2 \%$ and $42.3 \%$ respectively. On the 19th-21st day, lysine azo-albumin did not change, while in the main groups it was by $35 \%$ (D gr.) And $43.2 \%$ ( $\mathrm{D}_{1}$ gr.) Lower, compared to the baseline data and by $34 \%$ and $42.1 \%$ relative to $\mathrm{Kgr}$.

The azocollagen lysis in the first days exceeded the indicator of healthy persons by 2.2 times. On days 6-7 there was a decrease in it in all groups: by $43.8 \%$ (D gr.), $47.1 \%$ ( $\mathrm{D}_{1}$ gr.) And $38.0 \%$ (K gr) without significant difference between groups. On days 13-14, the probable decrease in this indicator was not found in any group. After 19-21 days after burn in all groups, the level of azocollagen lysis was lower, compared with the baseline - by $37.2 \%$, $62.6 \%$ and $32.9 \%$ respectively. However, in $\mathrm{D}_{1}$ gr. it was $38,4 \%$ lower than such in the D gr. and by $48.5 \%$, compared with $\mathrm{K}$ gr.

The intensity of proteolytic degradation of highmolecular plasma proteins (azocasein) in the first days was 2.6 times higher than normal. On days 6-7 it declined in $\mathrm{D}$ gr. by $29.3 \%$, in $\mathrm{D}_{1}$ gr. - by $31.3 \%$, and somewhat increased in K gr., Where it was $25 \%$ higher than in the main groups. On days 13-14 in the main groups lysis of azocasein was $31.5 \%$ and $42.0 \%$, respectively, lower than the indicator in $\mathrm{K}$ gr. On days $19-21$ in $\mathrm{D}$ gr. its level was $35.8 \%$, in $\mathrm{D}_{1}$ gr. - by $44.7 \%$ lower than the initial level. During this period in D1 gr. the level of azoxazein lysis was $31.8 \%$ lower than the indicator in $\mathrm{K}$ gr.

In the first 1-3 days after the burn of TFA plasma exceeded the norm by almost 3 times (Table 2).

In all groups the level of TFA during the entire period of observation did not change significantly, only in K gr. on days 19-21 it was $26.6 \%$ lower than the initial level. In this period, in the main groups the TFA was higher, compared with $\mathrm{K}$ gr., However, the probable difference of $32.8 \%$ was only in $\mathrm{D}_{1}$ gr. The level of NFA in the process of observation changed in the same way: on days 19-21 in the main groups it exceeded the index in K gr. by $31.4 \%$ and $33.2 \%$ respectively. The EFA level was about $47-49 \%$ of the TFA throughout the observation period. Only on days 19-21 in $\mathrm{D}_{1}$ gr. the EFA amounted to $51.3 \%$ of the TFA and was $32.5 \%$ higher than the index in $\mathrm{K}$ gr.

The results of the study indicate that common thermal burns are accompanied by an increase in the proteolytic activity of blood plasma relative to high molecular weight and low molecular weight proteins and collagen. It enhances the toxic load on the body, potentiates the alterative processes. At the

Changes in the proteolytic activity of blood plasma in patients with extensive thermal burns $\left(E_{440 / m l / h}\right)$

\begin{tabular}{|c|c|c|c|c|c|c|}
\hline \multirow{2}{*}{ Groups } & \multicolumn{3}{|c|}{ days1-3 } & \multicolumn{3}{|c|}{ days 6-7 } \\
\hline & Albumin & Collagen & Casein & Albumin & Collagen & Casein \\
\hline K gr. $n=30$ & $4,11 \pm 0,548$ & $0,59 \pm 0,097$ & $4,39 \pm 0,329$ & $3,69 \pm 0,649$ & $0,36 \pm 0,055$ & $4,50 \pm 0,383$ \\
\hline D gr. $n=28$ & $4,21 \pm 0,549$ & $0,53 \pm 0,125$ & $4,79 \pm 0,420$ & $2,99 \pm 0,303$ & $0,29 \pm 0,05$ & $\begin{array}{c}3,39 \pm 0,251 \\
P<0,05 \\
\end{array}$ \\
\hline$D_{1}$ gr. $n=24$ & $4,20 \pm 0,430$ & $0,36 \pm 0,076$ & $4,91 \pm 0,379$ & $2,83 \pm 0,219$ & $0,29 \pm 0,031$ & $\begin{array}{c}3,38 \pm 0,285 \\
P<0,05 \\
\end{array}$ \\
\hline \multirow{2}{*}{ Groups } & \multicolumn{3}{|c|}{ days $13-14$} & \multicolumn{3}{|c|}{ days 19-21 } \\
\hline & Albumin & Collagen & Casein & Albumin & Collagen & Casein \\
\hline K gr. $n=30$ & $4,30 \pm 0,720$ & $0,36 \pm 0,069$ & $4,85 \pm 0,440$ & $4,27 \pm 0,542$ & $0,39 \pm 0,081$ & $3,98 \pm 0,452$ \\
\hline D gr. $n=28$ & $2,73 \pm 0,267$ & $0,32 \pm 0,056$ & $\begin{array}{c}3,32 \pm 0,319 \mathrm{P}< \\
0,05\end{array}$ & $2,78 \pm 0,215$ & $0,33 \pm 0,046$ & $\begin{array}{c}3,08 \pm 0,260 \\
P<0,05 \\
\end{array}$ \\
\hline$D_{1}$ gr. $n=24$ & $2,46 \pm 0,117 P<0,05$ & $0,25 \pm 0,045$ & $2,81 \pm 0,142 \mathrm{P}<0,01$ & $2,42 \pm 0,119 P<0,01$ & $\begin{array}{c}0,20 \pm 0,026 \\
P<0,05 P_{1}<0,05\end{array}$ & $\begin{array}{c}2,71 \pm 0,233 \\
P<0,05\end{array}$ \\
\hline
\end{tabular}

Note: $\mathrm{P}$ - difference possibility with $\mathrm{K}$ gr.; $\mathrm{P}_{1}$ - difference possibility with $\mathrm{D}$ gr.; $\mathrm{n}$ - number of investigations 
Changes in fibrinolytic plasma activity in patients with common thermal burns (E440 $\mathrm{m} / \mathrm{h}$ )

Table 2

\begin{tabular}{|c|c|c|c|c|c|c|}
\hline \multirow{2}{*}{ Groups } & \multicolumn{5}{|c|}{ days 1-3 } & \multicolumn{3}{c|}{ days 6-7 } \\
\cline { 2 - 7 } & TFA & NFA & EFA & TFA & NFA & EFA \\
\hline K gr. $n=30$ & $0,92 \pm 0,091$ & $0,47 \pm 0,048$ & $0,45 \pm 0,044$ & $0,81 \pm 0,088$ & $0,41 \pm 0,045$ & $0,40 \pm 0,046$ \\
\hline D gr. $n=28$ & $0,94 \pm 0,081$ & $0,48 \pm 0,050$ & $0,45 \pm 0,051$ & $0,84 \pm 0,109$ & $0,43 \pm 0,061$ & $0,41 \pm 0,050$ \\
\hline$D_{1}$ gr. $n=24$ & $0,87 \pm 0,092$ & $0,44 \pm 0,043$ & $0,43 \pm 0,051$ & $0,89 \pm 0,077$ & $0,45 \pm 0,039$ & $0,43 \pm 0,037$ \\
\hline \multirow{2}{*}{ Groups } & \multicolumn{7}{|c|}{ days13-14 } & NFA & EFA & TFA & NFA & EFA \\
\cline { 2 - 7 } & TFA & NFA & 0,21 & $0,33 \pm 0,027$ & $0,35 \pm 0,028$ \\
\hline K gr. $n=30$ & $0,82 \pm 0,108$ & $0,42 \pm 0,048$ & $0,39 \pm 0,061$ & $0,67 \pm 0,053$ & $0,43 \pm 0,042 P<0,05$ & $0,38 \pm 0,051$ \\
\hline D gr. $n=28$ & $0,87 \pm 0,085$ & $0,44 \pm 0,046$ & $0,43 \pm 0,040$ & $0,81 \pm 0,090$ & $0,43 \pm 0,033 P<0,05$ & $0,46 \pm 0,042 P<0,05$ \\
\hline$D_{1}$ gr. $n=24$ & $0,90 \pm 0,056$ & $0,46 \pm 0,029$ & $0,45 \pm 0,031$ & $0,89 \pm 0,092 P<0,05$ & & \\
\hline
\end{tabular}

Note: $\mathrm{P}$ - difference possibility with $\mathrm{K}$ gr, $\mathrm{n}$ - number of investigations

same time, the FA of plasma increases, which may be considered as a protective mechanism aimed at improving the rheological properties of blood, preventing deepening of burn necrosis. Inclusion of enterosorbtion together with ITE antibacterial drugs into the complex treatment of burns contributes to a decrease of the proteolytic activity of the plasma, which provides a reduction of level of intoxication, and also allows to maintain a sufficiently higher level of FA. The latter is important in preventing the formation of blood clots and excessive formation of collagen, as the main substrate of the future scar.

\section{Conclusions}

1. Common deep thermal burns are accompanied by a significant increase in proteolytic and fibrinolytic activity of blood.

2. Inclusion of enterosorbtion in the integrated therapy of burns provides reduction of proteolytic activity and maintenance of a high level of FA of plasma, which reduces the risk of thromboembolic complications.

3. Combined use of enterosorption and ITE antibacterial agents (galvanoentersorption) with thermal burns provides a higher therapeutic effect.

\section{ПЕРЕЛІК ПОСИЛАНЬ}

1. Nielson C.B., Duethman NC., Howard J.M., M.M., Wood J.G., Burns: Pathophysiology of Systemic Complications and Current Management. J Burn Care Res. 2017;38:469-81.

2. Colohan SM. Predicting prognosis in thermal burns with associated inhalational injury: a systematic review of prognostic factors in adult burn victims. J Burn Care Res. 2010;31:529-39.

3. Petriuk B.V., Sydorchuk R.I., Khomko O.Y., Sydorchuk L.P., Petriuk T.A., Khomko B.O. The changes of burned wounds microbiocenosis under intratissue electrophoresis of antibacterial remedies. Eurn J Med. 2015;7(1):29-33.

4. Ковальчук А.О., Козинець Г.П. Оцінка стану кровопостачання ділянок термічного ураження та динаміки загоювання ран у хворих з опіковою травмою при місцевому застосуванні гідрогелевих регенеративних засобів та губчастих сорбуючих матеріалів. Харківська хірургічна школа. 2015;3:85-89.

5. Ravat F, Payre J, Peslages P, Fontaine M, Sens N. Burn: an inflammatory process. Pathol Biol (Paris). 2011;59:63-72.
6. Vaughn L, Beckel N. Severe burn injury, burn shock, and smoke inhalation injury in small animals. Part 1: burn clas- sification and pathophysiology. J Vet Emerg Crit Care (San Antonio). 2012;22:179-86.

7. Sheppard N.N., Hemington-Gorse S., Shelley O.P., Philp B., Dziewulski P. Prognostic scoring systems in burns: a review. Burns. 2011;37:1288-95.

8. Dries D.J. Management of burn injuries-recent developments in resuscitation, infection control and outcomes research. Scand J Trauma Resusc Emerg Med. 2009;17:14.

9. Koljonen V., Laitila M., Rissanen A.M., Sintonen H., Roine R.P. Treatment of patients with severe burns-costs and health-related quality of life outcome. J Burn Care Res. 2013;34:318-25.

10. Sartelli M., Abu-Zidan FM., Catena F., et al. Physiological parameters for Prognosis in Abdominal Sepsis (PIPAS) Study: a WSES observational study. World J Emerg Surgery. 2019;14:34. https://doi.org/10.1186/s13017-019-0253-2.

\section{REFERENCES}

1. Nielson C.B., Duethman NC., Howard J.M., M.M., Wood J.G., Burns: Pathophysiology of Systemic Complications and Current Management. J Burn Care Res. 2017;38:469-81.

2. Colohan SM. Predicting prognosis in thermal burns with associated inhalational injury: a systematic review of prognostic factors in adult burn victims. J Burn Care Res. 2010;31:529-39.

3. Petriuk B.V., Sydorchuk R.I., Khomko O.Y., Sydorchuk L.P., Petriuk T.A., Khomko B.O. The changes of burned wounds microbiocenosis under intratissue electrophoresis of antibacterial remedies. Eurn J Med. 2015;7(1):29-33.
4. Koval'chuk A.O., Kozynets' H.P. Otsinka stanu krovopostachannya dilyanok termichnoho urazhennya ta dynamiky zahoyuvannya ran u khvorykh z opikovoyu travmoyu pry mistsevomu zastosuvanni hidrohelevykh reheneratyvnykh zasobiv ta hubchastykh sorbuyuchykh materialiv. Kharkivs'ka khirurhichna shkola. 2015;3:85-9. [In Ukr.].

5. Ravat F, Payre J, Peslages P, Fontaine M, Sens N. Burn: an inflammatory process. Pathol Biol (Paris). 2011;59:63-72.

6. Vaughn L, Beckel N. Severe burn injury, burn shock, and smoke inhalation injury in small animals. Part 1: burn clas- 
sification and pathophysiology. $J$ Vet Emerg Crit Care (San Antonio). 2012;22:179-86.

7. Sheppard N.N., Hemington-Gorse S., Shelley O.P., Philp B., Dziewulski P. Prognostic scoring systems in burns: a review. Burns. 2011;37:1288-95.

8. Dries D.J. Management of burn injuries-recent developments in resuscitation, infection control and outcomes research. Scand J Trauma Resusc Emerg Med. 2009;17:14.
9. Koljonen V., Laitila M., Rissanen A.M., Sintonen H., Roine R.P. Treatment of patients with severe burns-costs and health-related quality of life outcome. J Burn Care Res. 2013;34:318-25.

10.Sartelli M., Abu-Zidan FM., Catena F., et al. Physiological parameters for Prognosis in Abdominal Sepsis (PIPAS) Study: a WSES observational study. World J Emerg Surgery. 2019;14:34. https://doi.org/10.1186/s13017-019-0253-2.

\section{ЗАСТОСУВАННЯ \\ ГАЛЬВАНОЕНТЕРО- \\ СОРБЦІЇ \\ У МУЛЬТИМОДАЛЬНОМУ ЛІКУВАННІ ХВОРИХ ІЗ ТЕРМІЧНИМИ ОПІКАМИ}

\author{
О. Й. Хомко, Б. В. Петрюк, \\ Л. П. Хомко, Р. І. Сидорчук, \\ Т. А. Петрюк, І. В. Зазуля
}

Резюме Мета - дослідити вплив ентеросорбції та їі поєднання $з$ внутрішньотканинним електрофорезом (ВТЕ) антибактеріальних препаратів на протеолітичну та фібринолітичну активність плазми крові у пацієнтів із термічними опіками.

Матеріал і методи. Ентеросорбційна детоксикація ентеросгелем застосовувалась у комплексному лікуванні 28 хворих із загальними термічними опіками II-IV стадій. Препарат призначали через 2-3 дні після опіку протягом 7-14 днів, залежно від тяжкості травми та проявів інтоксикаційного синдрому. У 24 пацієнтів це лікування було доповнене гальванізацією опікових ран з попереднім введенням антибактеріальних препаратів. ВТЕ розпочали через 3-4 дні після опіку з урахуванням чутливості мікрофлори до антибіотиків. Групу порівняння склали 30 пацієнтів з подібними площами та глибинами термічних опіків, які отримували традиційне лікування.

Результати та їх обговорення. Встановлено, що використання ентеросорбції в комплексному лікуванні опіків дозволяє знизити рівень необмеженого протеолізу, підвищити рівень фібринолітичної активності плазми крові. Ї̈̈ поєднання з ВТЕ антибактерійних засобів (гальваноентеросорбція) забезпечує досягнення кращих результатів лікування. Поширені глибокі термічні опіки супроводжуються значним підвищенням протеолітичної та фібринолітичної активності (ФА) крові. Включення ентеросорбції в комплексну терапію опіків забезпечує зниження протеолітичної активності та підтримання високого рівня ФА плазми, що знижує ризик тромбоемболічних ускладнень.

Висновок. Комбіноване застосування ентеросорбції та ВТЕ антибактеріальних засобів (гальваноентерсорбція) при термічних опіках забезпечує більш високий терапевтичний ефект.

Ключові слова: термічні опіки, ентеросорбція, внутрішньотканинний електрофорез, гальваноентеросорбція. 
ПРИМЕНЕНИЕ

ГАЛЬВАНОЕНТЕРО-

СОРБЦИИ

В МУЛЬТИМОДАЛЬНОМ

ЛЕЧЕНИИ БОЛЬНЫХ

С ТЕРМИЧЕСКИМИ

ОЖОГАМИ

А. И. Хомко, Б. В. Петрюк,

Л. П. Хомко, Г. И. Сидоренко,

Т. А. Петрюк, И. В. Зазуля
Резюме. Цель - исследовать влияние энтеросорбции и ее сочетание с внутритканевым электрофорезом (ВТЭ) антибактериальных препаратов на протеолитическую и фибринолитическую активность плазмы крови у пациентов с термическими ожогами.

Материал и методы. Энтеросорбционная детоксикация Энтеросгелем применялась в комплексном лечении 28 больных с общими термическими ожогами II-IV стадий. Препарат назначали через 2-3 дня после ожога в течение 7-14 дней, в зависимости от тяжести травмы и проявлений интоксикационного синдрома. У 24 пациентов это лечение было дополнено гальванизацией ожоговых ран с предварительным введением антибактериальных препаратов. ВТЭ начали через 3-4 дня после ожога с учетом чувствительности микрофлоры к антибиотикам. Группу сравнения составили 30 пациентов с подобными площадями и глубинами термических ожогов, которые получали традиционное лечение.

Результаты и их обсуждение. Установлено, что использование энтеросорбции в комплексном лечении ожогов позволяет снизить уровень неограниченного протеолиза, повысить уровень фибринолитической активности плазмы крови. Ее сочетание с ВТЭ антибактериальных средств (гальваноентеросорбция) обеспечивает достижение лучших результатов лечения. Распространеные глубокие термические ожоги сопровождаются значительным повышением протеолитической и фибринолитической активности (ФА) крови. Включение энтеросорбции в комплексную терапию ожогов обеспечивает снижение протеолитической активности и поддержания высокого уровня ФА плазмы, снижает риск тромбоэмболических осложнений.

Вывод. Комбинированное применение энтеросорбции и ВТЭ антибактериальных средств (гальваноентерсорбция) при термических ожогах обеспечивает более высокий терапевтический эффект.

Ключевые слова: термические ожоги, энтеросорбция, внутритканевый электрофорез, гальваноентеросорбция. 